\title{
Universiteit
}

Leiden

The Netherlands

\section{Cajamarca Quechua and the Expansion of the Huari State}

Adelaar, W.F.H.; Heggarty P., Beresford-Jones D.

\section{Citation}

Adelaar, W. F. H. (2012). Cajamarca Quechua and the Expansion of the Huari State. In B. J. D. Heggarty P. (Ed.), Archaeology and Language in the Andes. A Cross-Disciplinary Exploration of Prehistory (pp. 197-217). Oxford; New York: Oxford University Press. doi:10.5871/bacad/9780197265031.003.0008

Version: $\quad$ Not Applicable (or Unknown)

License: $\quad$ Leiden University Non-exclusive license

Downloaded from: https://hdl.handle.net/1887/70115

Note: To cite this publication please use the final published version (if applicable). 


\title{
Cajamarca Quechua and the Expansion of the Huari State
}

\author{
WILLEM F. H. ADELAAR
}

\begin{abstract}
Introduction
UnTIL ReCENTLY, THE STATE OF HuARi (AD 600-1000) has not played a significant role in the scenarios that have been proposed to account for the expansion of Quechua and its various branches and dialects. Ever since the beginning of the systematic mapping and investigation of the Quechua dialects in the 1960s, the area designated as the hearth of Quechua expansion has been the coast of central Peru, either with or without the inclusion of the neighbouring highlands (Torero 1964: 475-7; 2002: 86; Parker 1972: 115-19; CerrónPalomino 1987: 348). The region of Ayacucho, where the centre of the Huari state was located (Isbell 1988), ${ }^{1}$ has been treated as part of a language area associated with the Aymaran language family (also known as Aru or Jaqi ${ }^{2}$ ). Apart from Ayacucho, it would have included the Early Intermediate coastal culture of $\mathrm{Nazca}^{3}$ as well (Torero 1972: 91-106). The proximity to the Huari heartland of Aymara-related languages attested in an early colonial survey of 1586 contained in the Relaciones Geográficas de Indias (Jiménez de la Espada [1881-97] 1965), especially in the central and southern parts of the presentday department of Ayacucho, favoured the view that Aymaran languages were predominant throughout that area in the Early Intermediate Period (see, for instance, Torero 2002: 124). Nevertheless, there appears to be no direct

\footnotetext{
1 The site of the Huari capital is also known as Viñaque.

2 The term Aru 'language' was introduced by Torero (1972: 95), whereas an alternative denomination, Jaqi 'human', is used in publications by Hardman, the leading expert on Aymara and its sister language, Jaqaru (see, for instance, Hardman 1978). For the motivation for our use of the term Aymaran see Adelaar with Muysken (2004: 170).

3 The Nazca culture has been dated to AD 1-700 by Silverman and Proulx (2002).

${ }^{4}$ In early historical documents, the present-day town of Ayacucho is usually referred to as Huamanga.
} 
historical evidence for this assumption in so far as the Huari heartland and the surroundings of the town of Ayacucho ${ }^{4}$ itself are concerned.

The choice of central Peru as a setting for the Quechua homeland is understandable from a linguistic point of view because the greatest diversity of Quechua dialects is found on the Pacific slopes of the central Peruvian highlands, whereas the degree of linguistic conservatism is thought to be higher in central Peru than elsewhere. ${ }^{5}$ In the absence of evidence to the contrary, such considerations are often taken in comparative-historical linguistics as indicators of the place of origin of a language family (for a critical discussion see Heggarty 2007). Furthermore, there is also the need to establish a linguistic identity for the pre-Hispanic societies that inhabited the central Peruvian coast and of which the archaeological record extends far into the past. The coastal region of central Peru was at least partly Quechua-speaking in the sixteenth century but became Hispanicized soon after the European conquest, so that its original language situation remains unclear. Meanwhile, the location of Huari has been considered too far away from the central Peruvian hotbed of linguistic diversity to be of interest for a discussion on the Quechua homeland.

However, a pervasive and powerful expansion of the Quechua variety that was to become the southern Peruvian Quechua language seems to have occurred between the collapse of the Huari state and its counterpart in the Titicaca Basin, Tiahuanaco, around AD 1000, and the apogee of the Inca Empire in the fifteenth century. This seemingly unstoppable expansion of southern Peruvian Quechua into areas previously inhabited by speakers of Aymaran, Puquina, and other possible local languages calls for an explanation that the traditional model - which favours a slow and gradual expansion emanating from coastal centres (Torero 2002: 126-35) - cannot readily offer. Such an explanation can more easily be formulated in terms of a militarypolitical expansion. In the central Peruvian Andes no centres of great political power supported by military potential have been identified for the Late Intermediate Period (AD 1000-1400). During that period, the coastal centres of Pachacamac and Chincha stood out for their religious and economic radiation, respectively, but it does not seem realistic to assume that they could have imposed their language on to such a complex and rugged area as southern Peru, substituting all the autochthonous tongues in the process. Pachacamac had been an influential religious centre since the Middle Horizon and may have attracted migrants rather than sent them out, and Chincha was a sea-power unlikely to embark on military adventures in the mountainous

\footnotetext{
${ }^{5}$ See also Torero (2002: 86) for a list of arguments supporting the central Peruvian homeland
} hypothesis. 
interior. According to Torero (1984), the expansive potential of Chincha was first of all maritime and oriented towards Ecuador.

By contrast, the state of Huari with its military organization and expansive behaviour may have been powerful enough to impose its language in a lasting way on a linguistically diverse population consisting of dominated ethnic groups. It could have provided the driving force (cf. Beresford-Jones and Heggarty 2011) necessary for initiating a process of linguistic unification in the southern Peruvian Andes. And if the language of Huari was a variety of Quechua, its political expansion may have resulted in a situation in which the replacement of local languages with Quechua became a sort of automatic process that remained operational even after the demise of Huari as a military power. In this perspective, Quechuanized groups emerging from the Huari tradition, for instance, the Chanca federation, could have occupied strategic positions among a predominantly non-Quechuan population, which they gradually assimilated linguistically. Such a scenario can explain the fact that at the end of the fifteenth century the Inca rulers substituted Quechua for Aymara as their language of administration, even though at first the variety chosen was probably not the Quechua of the southern Peruvian highlands but the coastal variety of Chincha, as observed by the historical chronicler Martín de Murúa (Torero 1972: 86-7).

If we assume that Huari's role was instrumental in the genesis and expansion of southern Peruvian Quechua (Quechua IIC in the classification of Torero 1964), a similar stimulus may be hypothesized for the introduction of Quechua in other outlying areas, such as Cajamarca and Ferreñafe in the northern Peruvian Andes (part of Quechua IIA in the classification of Torero 1964). As a matter of fact, in its final stage of development the influence of the Huari state is traceable as far north as Viracochapampa, near modern Huamachuco (McCown 1945; Isbell 1988) on the upper reaches of the valley of the Cajamarca River, and in a small area to the east of the modern town of Cajamarca (Watanabe 2001). Although there is no consensus about the nature of this late Huari expansion (military conquest, religious proselytism, or intensive trade), it would not come as a surprise if expeditions emanating from Huari had left a trace in the form of Quechua-speaking communities in Cajamarca and its surroundings.

The purpose of this chapter is to establish whether a hypothesis stating that the modern Quechua dialect of Cajamarca (Cajamarca Quechua) can be attributed to migrations triggered by the Huari expansion is compatible with linguistic evidence. A positive answer to this question can add force to the proposal of a Quechua linguistic identity for Huari, which arose during the Cambridge meeting on Language and Archaeology in the Andes of September 2008. It may also lead to a reconsideration of the existing classifications of Quechua dialects. 


\section{Classification of Quechua Dialects}

Although recognized since colonial times, the view of Quechua as a family of closely related languages, rather than as a single language, became accepted in the mid-twentieth century. In a first comprehensive overview of the Quechua dialect situation, Parker (1963) distinguished two main branches of dialects: Quechua B, comprising the dialects of the central Peruvian highlands (roughly the highlands of Ancash, Huánuco, Pasco, Junín, and parts of Lima), and Quechua A, which includes all the varieties of Quechua spoken in the rest of Peru and beyond its borders. More refined and more widely used nowadays is Torero's classification of 1964. Torero's Quechua II (corresponding to Parker's Quechua A) is further subdivided into three sub-branches, Quechua IIA, Quechua IIB and Quechua IIC. (See Fig. 1.1 in the Introduction.)

In a reverse order of treatment, Quechua IIC roughly comprises the Quechua dialects spoken south of the Junín-Huancavelica department boundary, including the numerically important varieties of Ayacucho and Cuzco, as well as Bolivian and Argentinian Quechua. As far as its linguistic identity is concerned, Quechua IIC is a well-defined group with clear, recognizable features. Until the second half of the twentieth century, the southern Peruvian Quechua IIC dialects and the Quechua I dialects of central Peru constituted an unbroken Quechua-speaking area referred to as the Zona Continua, 'Continuous Zone' (Torero 1968: 293), which has now become fragmented as a result of a progressive language shift to Spanish (cf. Chirinos 2001).

Torero's sub-branch Quechua IIB consists of the Quechua dialects of Ecuador and Colombia, a number of varieties spoken in the Ecuadorian and Peruvian Amazon lowlands that originated as extensions of highland Ecuadorian Quechua, the dialects of Amazonas (Chachapoyas) and San Martín (Lamas) in north-eastern Peru, and the extinct dialect spoken in the sixteenth century on the central Peruvian coast around Lima and Pachacamac, as well as probably Chincha. Despite being geographically dispersed, Quechua IIB has a number of diagnostic features defining it as a unit, even though its separation from Quechua IIC may not be very old. Both Quechua IIB and Quechua IIC are distinct but related entities. By contrast, the coherence of Quechua IIA as a branch group has been under fire from the very beginning.

As was the case for Quechua IIB, the dialects that were assigned to Quechua IIA are geographically dispersed. They comprise a number of distinct dialects spoken in the highlands of the department of Lima, in the villages of Lincha and Laraos, both situated in the province of Yauyos but in different valleys and at a fair distance from each other, and in the community of Pacaraos located in the province of Huaral. Also classified as Quechua IIA were the dialects of Cajamarca and Ferrenafe situated in the northern Peruvian Andes. The former dialect is spoken in the department of Cajamarca 
(in the provinces of Cajamarca and Hualgayoc), whereas the latter is found in a highland section of the department of Lambayeque (in the provinces of Ferreñafe and Lambayeque) and in adjacent areas of the departments of Cajamarca and Piura.

In an article published in 1968, Torero offers a detailed discussion of the data that brought him to relate the Cajamarca and Ferreñafe varieties to the rest of Quechua IIA. For Cajamarca Quechua he proposes a homeland near Yauyos (close to Laraos and Lincha), and for Ferreñafe Quechua he hypothesizes an original location in the former province of Canta, which would have been close to Pacaraos. In a later publication, Torero (1972: 77-80) addresses the issue of the homeland of the two dialects in question in more general geographical terms. He assigns the origin of Cajamarca Quechua to the coastal river valleys situated between the Rímac River (Lima) and the town of Cañete, including the adjacent mountainous surroundings (namely, the southern coastal section of the department of Lima), whereas the roots of Ferreñafe Quechua are traced to the coastal river valleys situated between Chancay and Pativilca (that is, the northern coastal section of the department of Lima). In this perspective, the assumed migrations underlying the existence of Cajamarca and Ferreñafe Quechua would have been parallel to the expansion of Chínchay Quechua (Quechua IIB and IIC together), the origins of which are associated with the coastal region surrounding the town of Chincha (in the modern department of Ica). The hypothesis lying behind these developments is one of consecutive or simultaneous waves of Quechua-speaking groups migrating away from specific coastal locations into the mountainous interior, but avoiding the central highlands where Quechua I was already predominant.

As we anticipated, the Quechua IIA group, later renamed Yúngay (Torero 1972: 77) and subsequently Límay (Torero 2002: 80-2), has become the most controversial part of Torero's classification. The controversy concerns both the internal coherence of the Quechua IIA group and its association with Quechua II (rather than with Quechua I). Torero (1974: 30) himself expressed doubts about the validity of Quechua IIA as a unit. Taylor (1979: 171), the author of in-depth studies of the dialects of Ferreñafe and Laraos, opted for a subdivision of the Quechua dialects into three primary branches, in which he accorded Quechua IIA and part of the Quechua IIB dialects the status of a separate entity, denominated Quechua III, with the proviso that its homogeneity was not a proven fact. In his study of the Quechua dialects, Landerman (1991: 249) concludes that there is no reason to assume a special relation between the dialects of Cajamarca and Ferreñafe, on the one hand, and the dialects of the department of Lima attributed to Quechua IIA, on the other, because he finds no shared innovations and considers the word correspondences unconvincing. Heggarty (2005: 45) observes that the inclusion of individual Yauyos dialects within either Quechua I or Quechua IIA, on the basis 
of their vocabulary, is much less straightforward than was suggested in earlier literature.

The assignment of Pacaraos Quechua to Quechua IIA was put into doubt on account of its close association with Quechua I (Parker 1969b: 191-2; Adelaar 1984: 45-6). In many details of its complex word structure, Pacaraos Quechua coincides with the Quechua I dialect on which it borders. Notable exceptions are its unique 1st person ending involving contrastive stress and the use of the suffix of verbal subordination - 5 pa (instead of $-r$, which is predominant, though not exclusively so, in Quechua I). In addition, Pacaraos Quechua has a small stock of exclusive vocabulary, unexpected borrowings from an unidentified Aymaran language and words shared with a selection of Quechua dialects, such as QI Huanca, QIIa Ferreñafe and QIIc Ayacucho. All this seems to favour an interpretation of Pacaraos as a divergent variety of Quechua I with a number of Proto-Quechua retentions and a rich contact history (cf. the genealogical tree in Cerrón-Palomino 1987: 247).

The dialects of Laraos (Taylor 1990) and Lincha (Taylor 1984; Landerman 1991) are situated in an area of extreme linguistic diversity in which dialects tend to combine elements that are assignable either to the Quechua I group or to Quechua II. The dialects of Laraos and Lincha - as well as probably the dialects of Viñac and Madeán, communities that are geographically close to Lincha - are predominantly Quechua II, but they also contain elements that are characteristic of Quechua I and may be attributed to contact with Quechua I dialects. Laraos Quechua (Taylor 1990) has the appearance of a rather conservative Quechua II dialect with some unique features (e.g. a genitive case ending - $p i$ ) and a number of features that may have been borrowed from Quechua I, such as the verbal subordinator $-r$, the locative case ending -čaw, and a comparative case ending -naw. ${ }^{6}$

Remarkable is the absence of any trace of the external plural endings ( $-k u$ for 1st and 3rd person and -čik for 2nd person) that are used in Quechua IIC and part of Quechua IIB. By contrast, both Laraos and Lincha are reported to indicate plural internally on the verb. ${ }^{7}$ The suffixes that are used for this purpose, - paku-in Laraos (Taylor 1990:312) and - pa: ku-in Lincha (Landerman 1991: 254), can be associated with a plural element - $p a: k u$ - that is widely used in the southern Quechua I dialects. ${ }^{8}$ Since -pa: $k u$ - is otherwise absent from

\footnotetext{
${ }^{6}$ It is, of course, also possible to interpret these elements as retentions from Proto-Quechua. However, in the case of locative - ̌ca w, such an explanation is not likely. It apparently was a ProtoQuechua root that became grammaticalized in Quechua I, replacing an original locative case ending *-pi. (Compare the word * çawpi 'middle', which may have originated as a combination of that root*čaw with the locative case ending - pi still widely found in Quechua II.)

7 The notions of external and internal plural will be explained in more detail in the next section.

${ }^{8}$ In our phonetic notation, a colon (:) indicates that a vowel is long.
} 
Quechua II and contains a long vowel (unknown in Quechua II B and C), it seems likely that the dialects of Laraos and Lincha borrowed this element from one of the neighbouring Quechua I dialects. This situation suggests either that the Quechua IIA dialects of Yauyos separated from the Quechua IIB/C complex before the latter developed its system of external plural endings, or that this system was abandoned in the Yauyos dialects after they split off.

Most authors agree that the Quechua dialects of Cajamarca and Ferreñafe are closely related. On the basis of their vocabularies they are found to be akin, according to Torero's statistical word comparison (Torero 1972: 77-9). Both dialects share a number of structural innovations. Firstly, a verbal plural ending is derived from the root *lyapa- 'all' (although the root itself is no longer used with that meaning in the dialects at issue). Secondly, the suffix $-\check{s} u-$, originally used in verbal endings denoting a 3 rd person subject acting upon a 2nd person object ('he/she/it ... you'), has developed into a plain 2nd person object suffix ('... you') in a number of contexts. (The process is more advanced in Ferreñafe than in Cajamarca.) Furthermore, both dialects share some vocabulary that was probably inherited from a pre-Quechua language (e.g. inap (u) 'rainbow', lambaq 'insipid', mundžu 'navel').

In spite of these close similarities, Ferreñafe Quechua also has a number of suffixes associated with Quechua I (1st person object -ma- ('me') for Cajamarca -wa-, verbal subordination -r ('as, if, when') for Cajamarca -špa), instances of a vowel $a$ historically derived from the sequence *aya, suggesting an intermediate stage of vowel length as is still found in Quechua I, and some unusual coincidences in vocabulary with central Peruvian dialects, Pacaraos in particular, for example, yara- 'to wait', rata- 'to fall' (cf. Taylor 1996: 7). All this suggests that Ferreñafe is a mixed dialect combining elements of Cajamarca Quechua with those of a Quechua I dialect that had its origin further south. The history of the genesis of Ferrenafe Quechua could be a subject of further investigation.

In sum, there seems to be no reason to continue referring to Quechua IIA as a specific subdivision of Quechua II. As it seems now, Pacaraos may have to be reclassified as a divergent Quechua I dialect. Speaking in terms of a branching model, Laraos and Lincha (and possibly some of its neighbouring dialects) may constitute separate branches on the same level as Quechua IIB and IIC, although the data are too scarce to decide on whether or not they should be taken together. Cajamarca and Ferreñafe possibly constitute another branch of Quechua II on that level, although further research is needed in order to establish the nature of their interrelatedness. 


\section{The Position of Cajamarca Quechua: Sounds and Word Structure}

Cajamarca Quechua (Quesada 1973, 1976a, 1976b) is spoken in the neighbourhood of the capital town of the department of Cajamarca in northern Peru, in the provinces of Cajamarca and Hualgayoc. The main groups of Quechua speakers are found to the north and west of Cajamarca, especially in the district of Chetilla (west) and in the village of Porcón (north). There is evidence that Cajamarca Quechua until recently covered a wider area of use including localities to the south and east of Cajamarca as well (Pariamarca, Baños del Inca). Some of its speakers may still be found in these locations. By contrast, in most of the provinces of the department of Cajamarca the presence of Quechua has never been established. The exotic toponymy of the Cajamarca region bears witness to the former existence of non-Quechuan languages that may have lingered on until the nineteenth century. There is no documentation of these languages, except for place and family names.

From a historical point of view, Cajamarca Quechua is a conservative dialect of Quechua. In spite of some innovations, it retains most of the consonantal sound distinctions reconstructed for Proto-Quechua (Torero 1964; Parker 1969a), in particular, the contrast between the palatal affricate consonant $\check{c}$ and its retroflex counterpart $\check{c}$. This distinction is maintained in a large part of the Quechua I area of central Peru, either as such or in a modified way. The same holds for all the Quechua dialects that were assigned to the Quechua IIA construct, including Ferreñafe. Within the Quechua IIB branch, only the dialect of Chachapoyas or Amazonas, which is geographically close to Cajamarca Quechua, has maintained the $\check{c} / \check{c}$ distinction. By contrast, not a single dialect of the Quechua IIC branch preserves it, although traces of its past existence can be found in some of the dialects of that group (cf. Mannheim 1991: 121-2). Since we are dealing with an ancient sound distinction that has gradually disappeared from most Quechua-speaking areas, no conclusion can be reached from it about Cajamarca's place in the classification of dialects.

Another conservative aspect of Cajamarca Quechua is its retention of the Proto-Quechua opposition between the velar consonant $k$ and the uvular consonant $q$. The maintenance of this sound distinction effectively eliminates the possibility of an association of Cajamarca Quechua with the Quechua IIB group, for which the neutralization of the $k / q$ opposition constitutes a diagnostic feature. By contrast, the opposition is retained, as such or in a modified way, in Quechua I, in Quechua IIC, and in all the dialects assigned to the alleged Quechua IIA sub-branch, including Ferreñafe.

Finally, Cajamarca Quechua retains the distinction between two sibilant consonants $s$ and $\breve{s}$. This distinction has been reconstructed for Proto- 
Quechua, although there are different views as to the exact phonetic nature of the second sibilant (Landerman 1982; Cerrón-Palomino 1987: 121-4; Mannheim 1991: 153-76; Torero 1994). Quesada (1976b: 41-2) reports that the variety of Cajamarca Quechua spoken in Porcón still allows variation between an apical and a palatal realization of $\breve{s}$, a state of affairs that may have been inherited from an early stage of development of the language (cf. Cerrón-Palomino 1987: 157). A similar variation with marginal distinctiveness is still found in the Huanca dialects (Quechua I). The original contrast between the sibilants $s$ and $\check{s}$ disappeared from almost all the Quechua IIC dialects in favour of alveolar $s$, presumably during the colonial period. ${ }^{9}$

Cajamarca Quechua has no distinction of vowel length, and there are no strong indications that such a distinction ever existed in that dialect. Possible counterexamples are the verbs pari- 'to fly' and puka- 'to blow', which correspond to pa:ri- and pu:ka- respectively in Quechua I, but pawa- and puku-in Quechua IIB/C. If we assume that these two verbs could have been borrowed from a Quechua I dialect with simultaneous loss of vowel length, we may establish that one of the most characteristic innovations of Quechua I (and of some of the other dialects assigned to the Quechua IIA sub-branch) is not shared by Cajamarca Quechua. Again, in this respect, Cajamarca Quechua may hold a conservative position.

The consistent conservatism that characterizes the sound system of Cajamarca Quechua is compatible with the hypothesis of an early separation from the dialect complex that was to develop into southern Peruvian Quechua (Quechua IIC) and Ecuadorian-Coastal Quechua (Quechua IIB) and which may have been the language of the Huari capital and state. We shall now look at the structural properties of Cajamarca Quechua and see whether further confirmation can be found in that domain.

The shape of the 1st person ending that indicates a non-future subject with verbs and a possessor with nouns has been treated as a diagnostic feature justifying an original split between Quechua I and Quechua II (Torero 1968: 292). In this respect, Cajamarca Quechua firmly sides with Quechua II as it has two distinct endings for 1st person, $-n i$ and $-y$ ('I', 'my'). In Cajamarca Quechua, the ending $-n i$ is used in the indicative mood, except for the future tense, in which, as in other Quechua dialects, the 1st person is expressed by a special ending $-s ̌ a q$ ('I will'). The suffix $-y$ is used on all other verb forms, as well as on nouns to indicate possession ('my').

For the 1st person subject ending used in the past tense of the indicative mood, Quesada (1976b: 122-3) registers the alternative forms $-y$ and $-y n i$, in

\footnotetext{
${ }^{9}$ A remnant of the original contrast between $s$ and $\check{s}$ is retained in the Argentinian dialect of Santiago del Estero (de Reuse 1986; Adelaar 1995). Cuzco Quechua has reintroduced the distinction as a result of secondary developments.
} 
addition to -ni, for Cajamarca Quechua. This suggests that, originally, -ni may have been restricted in its use to the unmarked or present tense of the indicative. If we assume that $-y$ was once the only 1 st person subject ending, it may have been replaced in early Quechua II by - ni in the unmarked tense in order to avoid coincidence with the endings of the infinitive and the 2 nd person subject imperative, both of which are also - $y$ (see Adelaar 1984 for an elaboration of this hypothesis). As far as Cajamarca Quechua is concerned, such a possibility would place its origin in a subsequent stage of development of the Quechua II branch, when the special 1st person subject ending -ni of the indicative unmarked tense began to invade other sections of the verbal system on an analogical basis.

The suffix -wa-, 1st person object ('me'), is identical in Cajamarca to its equivalent in Quechua IIB/C. The corresponding Quechua I suffix is - ma:-. It emerges as $-m a-$ in the Ferreñafe dialect, which has no vowel length distinction. It appears to be a token of a secondary link that connects Ferreñafe and Quechua I without extending to Cajamarca. Arguably, -ma:- could have been derived from a sequence ${ }^{*}-m u-w a-$, containing the suffix - $w a$ - following the suffix -mu-, which indicates a 'direction towards the speaker' (Adelaar 1982: 65; Torero 2002: 69). ${ }^{10}$ If this analysis is correct, it would imply that Cajamarca Quechua not only sides with Quechua IIB/C in so far as the 1st person object suffix is concerned, but also that it preserves a form inherited from Proto-Quechua.

There are two verbal suffixes for (non-imperative) 2 nd person subject ('you ...'): -nki and -(y)ki. ${ }^{11}$ Cajamarca shows the same distribution of these as Quechua IIC, except that in the past tense it uses $-y k i$ instead of $-n k i .^{12} \mathrm{In}$ this respect, Cajamarca and Ferreñafe Quechua side with Quechua I, where the second person subject ending is also $-y k i$ in the past tense. At least one Quechua II dialect, Quechua IIB Chachapoyas, uses both options (Taylor 1994: 136). We assume that the maximally restricted use of -nki represents the original situation, in which case Cajamarca Quechua would hold a conservative position, and its similarity with Quechua I could be based on a common retention.

\footnotetext{
${ }^{10}$ Cerrón-Palomino (1987: 149) casts doubt on this analysis on account of the occurrence of -mu-ma:- in Huanca (Quechua I). However, the Huanca dialects border on Ayacucho Quechua (IIC), where the sequence - $m u$ - $w a$ - is common. It could easily have provided a model for a newly coined -mu-ma:-

${ }_{11}$ After a base or a connective element ending in $-i$ - one finds $-k i$ instead of $-y k i$.

12 Taylor (1994: 89) observes that all the Yauyos dialects originally attributed to Quechua IIA use $-n k i$ instead of $-y k i$ in the past tense. No matter how this anomaly is interpreted (borrowing from Ayacucho Quechua?) it does not speak in favour of a link Cajamarca-Yauyos as proposed in Torero (1968).
} 
One of the most intriguing issues concerning the Quechua of Cajamarca is the way in which it encodes a 2 nd person object ('... you'). In this domain, Cajamarca Quechua exhibits a peculiar mix of innovative behaviour and conservatism. With Ferreñafe Quechua, most of Bolivian Quechua, and Santiago del Estero Quechua in Argentina, Cajamarca Quechua shares the innovative development of an inverse suffix $-\check{s} u$ - into an universal 2nd person object suffix. ${ }^{13}$ The suffix $-\check{s} u$ - was originally restricted to a seemingly anomalous suffix combination still used today in a majority of the Quechua dialects. This combination, $-\check{s} u-\ldots-n k i /-(y) k i$, indicates the transition ${ }^{14}$ of a 3 rd person subject affecting a 2 nd person object ('he/she/it ... you'). The extension of the use of $-\check{s} u$ - implies that it acquires the function of a straightforward 2nd person object suffix in a more ample set of transitions ('I ... you', 'he/she/it ... you'). This innovation appears to have begun in the future tense, where a combined ending -šu-nqa refers to a 3 rd person subject affecting a 2 nd person object ('he/she/it will ... you') and -nqa is the regular subject ending for 3rd person ('he/she/it will'). The dialects differ in how widely they accept the use of $-\check{s} u$ - as a 2 nd person object suffix, in particular, in those cases where the corresponding subject is 1 st person, rather than 3 rd.

However, for the transition of a 1st person acting upon a 2nd person (' $\mathrm{I}$ .. you'), ${ }^{15}$ Cajamarca Quechua also preserves the ending $-q$, which is common in the Quechua I dialects (with a variant $-k$ found in the Huanca dialects of the Mantaro Valley). In Cajamarca Quechua, the ending $-q$ can be used either by itself, or, redundantly, in combination with the innovative 2nd person object suffix $-\check{s} u-$ (' $\ldots$ you'). Additionally, an ending $-y k i$ is used for the same purpose in the unmarked present tense and in compound tenses derived from it. (For an overview of the possibilities, see Quesada 1976b: 125-6.)

The distribution of the endings $-q$ and $-y k i$ in Cajamarca is highly significant. In Quechua IIC, $-y k i$ is the ending designed to indicate the transition of a 1st person subject affecting a 2 nd person object ('I ... you'). However, as opposed to $-q$ in Quechua I, its use is restricted to those environments in which the 2nd person subject ending ('you ...') is represented by -nki and not by $-(y) k i$. In other environments, there is a coincidence of the ending indicating the transition of a 1 st person subject affecting a 2 nd person object (' $\mathrm{I}$... you') with the ending indicating a 1st person subject alone ('I'). The result is

\footnotetext{
${ }^{13}$ Inverse suffixes change the role of an accompanying subject ending into that of an object. For the interpretation of $-\check{s} u$ - as an inverse suffix, see Adelaar (2009).

${ }^{14}$ The term 'transition' is borrowed from the Andean colonial grammar tradition and refers to verbal endings that indicate the grammatical person of both a subject (actor) and an object (patient, recipient, etc.).

${ }^{15}$ For the expression of this transition in the future tense most Quechua dialects, regardless of branch, have reflexes of an ending *-šqayki ('I will . . . you').
} 
a defective paradigm, in which a 2nd person object cannot be indicated by a suffix in all environments.

We may assume that $-q$, being less restricted in its use than $-y k i$, represents the original transitional ending of a 1st person subject affecting a 2 nd person object in Quechua. Its eventual replacement with $-y k i$ in Quechua II may be due to the circumstance that $-q$ is also the ending of the agentive nominalizer ('the one who ...') and hence of the (compound) habitual past tense ('he/she used to'), which is based on that form. If indeed $-y k i$ was substituted for $-q$ at an early stage of the development of Quechua II, this innovation would have begun in the unmarked (present) tense of the indicative mood. It is exactly the stage of development captured by Cajamarca Quechua. When we disregard the parallel development of an innovative 2nd person object suffix $-\check{s} u$-, Cajamarca Quechua again betrays itself as a highly conservative member of the Quechua II branch. In addition, Cajamarca is probably the only dialect that bears witness to a process of substitution that lay at the basis of what is now one of the diagnostic differences between the two main branches of Quechua.

Quechua dialects can be subdivided depending on the way in which they express plurality of a speech act participant. Such expressions can be either internal or external. Suffixes that indicate the plural internally are located within the area of verbal derivation, that is, between a verbal base and its suffixes referring to tense, mood, and person (e.g. Pacaraos wata-n '(s)he ties', wata-ri- $n$ 'they tie', where -ri-indicates the plural). Quechua dialects that indicate the plurality of speech act participants verb-internally generally do not have at their disposal a suffix to pluralize nominal possessors. Suffixes that indicate the plural externally are attached after the personal endings on a noun or verb form. They can assign plurality to a verbal subject or object, as well as to a nominal possessor (e.g. Ayacucho wata- $n$ '(s)he ties', wasi- $n$ 'his/ her house'; wata-n-ku 'they tie', wasi-n-ku 'their house', where $-k u$ indicates the plural). Internal plurals are found in the Quechua I dialects, in Pacaraos Quechua, and in the Quechua dialects of Yauyos, including Laraos and Lincha, which may have borrowed them from Quechua I. External plurals are found in all Quechua IIB and IIC dialects, as well as in Cajamarca and Ferreñafe Quechua.

Although Cajamarca and Ferreñafe Quechua share the principle of external plural indication with Quechua IIC, the respective suffixes are both formally and functionally different. As we have seen, Quechua IIC dialects use a set of two suffixes, $-k u$ and -chik (or variants of the latter). They are distributed according to person, $-k u$ for 1 st and 3 rd person, and -čik for 2 nd person. These plural suffixes are well preserved in the Quechua IIC dialects. The Quechua IIB dialects are divided, in that some of them (Ecuadorian Quechua, sixteenth-century Lima Quechua) feature the same set of plural suffixes as 
Quechua IIC, whereas others (Chachapoyas and Lamas) use (variants of) -sapa, originally a nominal suffix with the meaning 'rich in ...', 'with many ...' Lamas Quechua uses both -sapa and, for 2nd person only, -čci (*-čik) (Taylor 1979: 181). Cajamarca and Ferreñafe Quechua use variants of *vapa'all', but -sapa is equally attested in Cajamarca Quechua (Quesada 1973: 51, 81). There are no indications that the set of two external plural suffixes found in Quechua IIC, and partly also in Quechua IIB, ever existed in Cajamarca, or in Ferreñafe. These dialects feature external plural like most of the other Quechua II dialects, but they have not inherited the characteristic plural suffixes with their specialized functions that developed in the south of Peru and on the Peruvian central coast. Therefore, it is likely that the ancestor of Cajamarca and Ferreñafe Quechua split off from Quechua IIB/C before the system with two specialized external plural suffixes developed in the latter branch. ${ }^{16}$

Quechua dialects are divided with respect to the shape of the suffix of verbal subordination that is used when the subjects of both a subordinate clause and the main clause to which it is subordinated are identical. In Cajamarca, this is indicated by means of the ending -špa ('as, if, when'), which is the option found in most of Quechua II. Ferreñafe, with the suffix - $r$, aligns with Quechua I.

The domain of verbal derivation in Cajamarca Quechua does not hold too many surprises, but a few issues should be mentioned. Like Quechua IIB, Cajamarca Quechua lacks the characteristic lowering to $a$ that affects a back vowel $(u)$ in verbal suffixes before certain other suffixes (-mu-, -pu-, - či-, etc.) in Quechua I, in Quechua IIC, and in Ferreñafe (Taylor 1994: 61). Since a phonologically unmotivated rule of this kind can easily become obsolete, there is no reason to assume a close relationship between Cajamarca Quechua and Quechua IIB on this sole basis.

Along with the verbal suffix $-k u$-, which indicates a reflexive or mediopassive, both Cajamarca and Ferreñafe Quechua distinguish another suffix of verbal derivation, $-k a$ - This suffix is not found in the rest of Quechua II, which only has $-k u-{ }^{17}$ but it is widely attested in Quechua I (where the vowel of $-k a$ :- is predictably long). The meaning of Cajamarca Quechua $-k a-$, that of a passive or an accidental, unplanned action, resembles the meaning of $-k a$ :- in Quechua I. There are two possible explanations for this state of affairs. The suffix - $k a$ - may be an element inherited from Proto-Quechua, or it could

\footnotetext{
16 Note, however, that the system with two specialized plural suffixes is also absent from the Quechua B dialects of Chachapoyas and Lamas, located to the east of Cajamarca.

${ }^{17}$ Note that $-k u$ - can change to $-k a$ - before a number of other verbal suffixes. As we have seen, this rule is not operational in Cajamarca Quechua.
} 
have been borrowed from a Quechua I dialect. In the former case the suffix $-k a$ - would have been lost in the Quechua IIB/C dialects. ${ }^{18}$ Nevertheless, the existence of this suffix $-k a$ - is one of the few structural issues in which both Cajamarca and Ferreñafe Quechua appear to side with Quechua I.

In the case of the progressive aspect suffix $-y k a-(-y a-$ in Ferreñafe), Cajamarca Quechua at first sight also appears to side with Quechua I. However, the same suffix is found in the Quechua IIA dialects of Yauyos (except Laraos, see Taylor 1994: 89), as well as in the Quechua IIB dialects that are spoken in an area to the east of Cajamarca, namely, Chachapoyas (Amazonas) and Lamas (San Martín). Furthermore, the Quechua IIC suffix for progressive aspect -čka- (with numerous variants) reappears in Cajamarca in a slightly different form, - çka-, and denotes an anticipated action (Quesada 1976b: 133-4). Curiously, this function resembles the way in which -čka:- is used, as a specialized alternative for the progressive aspect suffix $-y(k) a$ :-, in the Huanca dialects, which belong to Quechua I (Cerrón-Palomino 1976: 212-13). These dialects border on the Quechua II dialect of Ayacucho, which only has - čka-. In this case, it seems that both Cajamarca Quechua and the Huanca dialects preserve an original state of affairs of two competing suffixes with related but slightly different meanings.

Also in its structural composition, Cajamarca Quechua is found to hold a conservative position, as has now been confirmed by several cases. This supports the view of an early date of separation from the remainder of Quechua II and is compatible with the hypothesis of an early migration departing from a powerful centre in the southern Peruvian highlands. If Proto-Quechua II was indeed the language of a Huari state, a group of migrants from the Huari homeland could have introduced that language to the area of Cajamarca shortly before AD 1000 .

\section{The Position of Cajamarca Quechua: Vocabulary}

The vocabulary of Cajamarca Quechua (Torero 1968; Quesada 1976a) does not hold many surprises. Apart from a small amount of words of nonQuechuan origin (possibly from the substratum language Culle) and a few idiosyncratic elements shared with Ferreñafe (including a possible isolated loan from Aymara, čupika 'red'), there are but few vocabulary items that do not occur in other Quechua dialects as well. As might be expected, Cajamarca

${ }_{18}$ The affix -kaya-, attested in some of the Quechua IIC dialects (Parker 1973: 7), is semantically far apart from Cajamarca and Quechua I - $k a(:)$-. However, a possible remnant of $-k a$ - may be found in the verb base puchuka- 'to end', found in Quechua IIB and C. 
Quechua presents a mix of southern (Quechua II) vocabulary with vocabulary associated with the Quechua I dialects of the central-northern Peruvian highlands. Sometimes 'southern' and 'central-northern' vocabulary coexist, as in the case of urma- and iški- 'to fall'. The former is widely used in Quechua IIC dialects, and the latter in Quechua I.

The composition of the Cajamarcan vocabulary may be interpreted as the product of a southern (Quechua II) element, which would have been brought to Cajamarca with the initial group of migrants, and an areal component that could be the result of interaction with geographically nearby dialects such as the Quechua I varieties of northern Ancash and the dialects of Chachapoyas (Amazonas) and Ferreñafe (Lambayeque). Even though at present there is no longer a geographical contiguity between these dialects, such a contiguity, as well as regular trading contacts, may have existed in the past. In comparison to Ferreñafe, Cajamarca Quechua retains substantially more southern vocabulary, but not as much as the Chachapoyas and Lamas dialects. These dialects belong to the Quechua IIB subdivision and probably reached their modern locations centuries later than Cajamarca Quechua. ${ }^{19}$ Furthermore, the existence of some Cajamarca words may be ascribed to the domination of the Incas. A possible example of such influence is punčaw 'day, daytime' (Quesada 1976a), a term of southern origin. If it were inherited, one would expect the affricate to be retroflex, as suggested in Torero (1968: 308).

As regards the presence in Cajamarca Quechua of words normally associated with the central-northern Quechua I dialects, there may be a simpler explanation than the one offered above. Cajamarcan vocabulary that appears to be shared with Quechua I in an exclusive way can also be attributed to a common inheritance from Proto-Quechua. Such vocabulary would have been replaced with new terms in the southern Peruvian Quechua II dialects after Cajamarca Quechua became separated from them. As a matter of fact, examples of central-northern vocabulary have also been found in documents relating to areas dominated or formerly dominated by Quechua IIB/C dialects, for instance, akra- 'to choose' in Chincha, and kaša 'thorn' in the Lucanas area in south-western Ayacucho (Torero 2002: 132-4).

Another possible example of common inherited vocabulary is the verb rika- / rika:- 'to see', which is found in Quechua I, Cajamarca, and Ferreñafe Quechua, as well as in the Quechua dialects of Yauyos, including Laraos and Lincha. Since both Quechua IIB and C have riku-, rather than rika(:)-, it seems reasonable to assume that the form riku-developed in Quechua II after

\footnotetext{
19 Landerman, in Doherty Vonah et al. (2007: 16), shows on the basis of ethnohistorical evidence that Lamas Quechua originated in the Chachapoyan highlands, obviously before Chachapoyas Quechua developed its own highly distinct character.
} 
the separation of Cajamarca-Ferreñafe and the Yauyos dialects (possibly by a merger of the root rika- with the reflexive suffix $-k u$-).

Torero (1968) presents a comparison of one hundred vocabulary items in different dialects, including Cajamarca and Ferreñafe Quechua. As we have mentioned earlier, he concludes, on the basis of this comparison, that Cajamarca Quechua must have proceeded from an area close to the province of Yauyos. In Torero (1972) he redefines the Cajamarca Quechua homeland as a coastal stretch situated between the valleys of Lurín and Cañete, that is, the southern half of the coastal section of the department of Lima. The origins of Ferreñafe Quechua are assigned to a similar stretch in the northern half of the department of Lima. Even though it seems possible to find some common elements between Ferreñafe Quechua and the Quechua dialects spoken on the central-northern Pacific slopes of Lima department, we agree with Landerman (1991) that the association of Cajamarca with Yauyos and southern coastal Lima remains unsubstantiated. Furthermore, there seems to be no archaeological evidence in support of such a link. The dialects of Laraos and Lincha (possibly with other adjacent varieties) may represent a similar stage of differentiation from Quechua IIB/C as Cajamarca Quechua does, but there are no clear indications that the latter dialect formed a common branch with the Yauyos varieties at any time. This observation undermines the assumption of a coastal origin for Cajamarca Quechua and leaves room for a different scenario, in which Quechua was introduced to the Cajamarca area from a centre of power in the southern highlands, namely Huari.

\section{Discussion and Conclusion}

The data pertinent to linguistic structure allow for a classification of Cajamarca Quechua and the Laraos-Lincha dialect cluster in Yauyos within Quechua II. Considering their conservative character and the lack of innovations shared with Quechua IIB/C, they were probably among the first dialects to separate from early Quechua II. This does not mean that they are to be treated as a unit because there is no positive evidence linking them specifically.

From a geographical point of view, it is not at all implausible that both Cajamarca Quechua and the abovementioned Yauyos dialects had their origins, by migration or otherwise, in the present-day departments of Huancavelica and Ayacucho. Although in the sixteenth century parts of the department of Ayacucho were inhabited by speakers of Aymaran languages, Quechua was also well represented, and there is no indication that its arrival in the area was recent. The centre of the Huari state, situated in northern Ayacucho, where no Aymaran languages have been attested, is a possible candidate for having triggered a linguistic expansion towards Cajamarca and Yauyos. 
In the case of Yauyos, the assumed expansion would have consisted in a gradual penetration of Quechua II speakers into an adjacent area previously occupied by Quechua I and Aymaran languages. In the case of Cajamarca, long-distance military conquest, possibly accompanied by a forced displacement of local ethnic groups speaking an early form of Quechua II, may provide an explanation. If Huari were a powerful, militarily organized state, it would have been able to achieve this, although more peaceful scenarios are equally conceivable. The route chosen for the migration to Cajamarca may have followed an Andean trajectory, probably through the Callejón de Huaylas, where much Huari material has been found (Isbell this volume; David Beresford-Jones, personal communication). A coastal route, as suggested before, seems much less likely.

From the point of view of its vocabulary, Cajamarca Quechua has remained close to the mainstream of the Quechua dialects. This may seem in conflict with the conservative nature of its structure and sound system, which suggests a greater time-depth for its separation from Quechua II than do the vocabulary data. However, if we assume that Cajamarca Quechua has been as conservative in generating new vocabulary as in conserving its structure, this apparent contradiction need not be problematic. It may be noted that the more fundamental division between Quechua I and Quechua II is also primarily based on the use and distribution of structural elements, whereas vocabulary differences offer a less consistent picture.

The above observations have consequences for a chronology of the historical developments that led to the present-day internal diversity of the Quechua language group. The northward expansion of Cajamarca Quechua, originally placed in the sixteenth century (Torero 1968: 315), must have predated the separation of Quechua IIB from Quechua IIC, which occurred well before the arrival of the Spaniards. If we allow archaeological evidence to influence the chronology, the expansive stage of the Huari state, shortly before it ceased to exist (about AD 900), would have been the most likely moment for such a northward expansion to occur.

The distinction between Quechua I and Quechua II, which has an ampler structural basis than that between Cajamarca Quechua and Quechua II B/C, suggests an earlier time of separation for the former than for the latter. In the case of Quechua I, one may think of a gradual penetration of central Peru from the centre of the Huari state during the second half of the first millennium, which could have resulted in a highly diverse dialect continuum in the central Peruvian Andes. However, the alternative view of an ancient and slightly diversified Quechua-speaking area in central Peru, of which Huari would have been the southernmost outpost, appears to be equally attractive. In the former perspective, Huari would have been the homeland of Quechua as a whole, and in the latter perspective, of Quechua II only. 
The likelihood that Quechua IIB became separated from Quechua IIC at a relatively recent date, when the common ancestor of both groups could have been located in the Ayacucho-Huancavelica area, also calls for some interesting reflections. Quechua IIB and IIC probably acquired their system of plural endings during an exclusive common stage of development following the split-off of Cajamarca Quechua. In that case, the Chachapoyas-Lamas subbranch of Quechua IIB would have (partly) lost these plural endings, replacing them with one of the plural endings of the Cajamarca dialect (or vice versa). More significant for the historical identity of Quechua IIB, however, is the loss of the distinction between velar $k$ and uvular $q$, which sets apart Quechua IIB from the rest of Quechua. Cerrón-Palomino (1990: 361) argues with ample cross-linguistic illustrations that such a loss is likely to occur in a situation of language contact, presumably with a language that does not have the distinction between velar and uvular consonants. Since in the sixteenth century Quechua IIB was particularly strongly represented on the central Peruvian coast and in areas such as Ecuador that initially may have been Quechuanized by a coastal route (cf. Torero 1984), one may speculate that Quechua IIB lost its uvular-velar distinction through contact with an unidentified coastal language that did not have that distinction.

The above scenario focusing on Ayacucho and Huancavelica as the centre of expansion of Quechua II (or even Quechua as a whole) has the advantage of eliminating most of the unlikely coast-to-Andes migrations proposed in the past, which are not supported by archaeological evidence. The only putative migrations of this kind that remain standing relate to the Quechuanization of Chachapoyas, possibly with a group of mitimaes of coastal origin, and to the Quechuanization of Ecuador by pre-Inca traders. In this perspective, Quechua emerges as a language that had its origin in the Andes rather than on the coast.

To end this contribution, we would like to recall that none of the scenarios presented in this chapter can provide a full picture of reality as long as the history of the Aymaran languages and the intensive contact history of the Aymaran and Quechuan language families are not fully accounted for. Our observations have to be viewed as a contribution to a better understanding of the possibilities of interpretation of the linguistic history of the Peruvian Andes, not as a final word. 


\section{References}

Adelaar, Willem F.H. 1982. Incidental changes in the suffix part of Quechua verbs. Lingua 56, 59-73.

Adelaar, Willem F.H. 1984. Grammatical vowel length and the classification of Quechua dialects. International Journal of American Linguistics 50, 1, 25-47.

Adelaar, Willem F.H. 1995. Raíces lingüísticas del quechua de Santiago del Estero, in Actas II Jornadas de Lingüística Aborigen (Buenos Aires 1994), ed. A.V. Fernández Garay and J.P. Viegas Barros. Buenos Aires: Facultad de Filosofía y Letras, Instituto de Lingüística, 25-50.

Adelaar, Willem F.H. 2009. Inverse marking in Andean languages, a comparative view, in The Linguistics of Endangered Languages: Contributions to Morphology and Morpho-Syntax, ed. W.L. Wetzels. Utrecht: Netherlands Graduate School of Linguistics (LOT), 171-85.

Adelaar, Willem F.H., with Pieter C. Muysken 2004. The Languages of the Andes. Cambridge: Cambridge University Press.

Beresford-Jones, David and Paul Heggarty. 2011. What role for language prehistory in redefining archaeological 'culture? A case-study on new horizons in the Andes, in Investigating Archaeological Cultures: Material Culture, Variability and Transmission, ed. B. Roberts and M. Vander Linden. New York: Springer, 355-86.

Cerrón-Palomino, Rodolfo M. 1976. Gramática quechua Junín-Huanca. Lima: Ministerio de Educación and Instituto de Estudios Peruanos.

Cerrón-Palomino, Rodolfo M. 1987. Lingüística quechua. Cuzco: Centro Bartolomé de Las Casas.

Cerrón-Palomino, Rodolfo M. 1990. Reconsideración del llamado 'quechua costeño'. Revista Andina 8, 2(16), 335-409.

Chirinos Rivera, Andrés 2001. Atlas lingüístico del Perú. Lima and Cuzco: Ministerio de Educación and Centro Bartolomé de Las Casas.

Doherty Vonah, Jaime, Artidoro Tuanama Satalaya, Inocente Sangama Sangama, and Francisco Lozano Lozano. 2007. Rikchak-laya Rimana Tarina. Diccionario del quechua de San Martín. Lamas: Academia Regional de Kechwa de San Martín.

Hardman, Martha J. 1978. Jaqi: the linguistic family. International Journal of American Linguistics 44, 146-53.

Heggarty, Paul. 2005. Enigmas en el origen de las lenguas andinas: aplicando nuevas técnicas a las incógnitas por resolver. Revista Andina 40, 9-80.

Heggarty, Paul. 2007. Linguistics for archaeologists: principles, methods and the case of the Incas. Cambridge Archaeological Journal 17(3), 311-40.

Isbell, William H. 1988. City and state in Middle Horizon Huari, in Peruvian Prehistory, ed. R.W. Keatinge. Cambridge: Cambridge University Press, 164-89.

Jiménez de la Espada, Marcos. 1965 [1881-97]. Relaciones geográficas de Indias: Perú, 3 vols. Biblioteca de Autores Españoles 183-5. Madrid: Atlas.

Landerman, Peter N. 1982. Las sibilantes castellanas, quechuas y aimaras en el siglo XVI: un enigma tridimensional, in Aula quechua, ed. R.M. Cerrón-Palomino. Lima: Signo Universitario, 203-34.

Landerman, Peter N. 1991. Quechua dialects and their classification. Ph.D. dissertation, University of California, Los Angeles. 
McCown, Theodore D. 1945. Pre-Incaic Huamachuco: survey and excavation in the region of Huamachuco and Cajabamba. University of California Publications in American Archaeology and Ethnology 39(4), 223-400.

Mannheim, Bruce. 1991. The Language of the Inka since the European Invasion. Austin: University of Texas Press.

Parker, Gary J. 1963. La clasificación genética de los dialectos quechuas. Revista del Museo Nacional 32, 241-52.

Parker, Gary J. 1969a. Comparative Quechua Phonology and Grammar II: ProtoQuechua Phonology and Morphology. Working Papers in Linguistics 2. Honolulu: Department of Linguistics, University of Hawaii, 123-47.

Parker, Gary J. 1969b. Comparative Quechua Phonology and Grammar IV: the Evolution of Quechua A. Working Papers in Linguistics 9. Honolulu: Department of Linguistics, University of Hawaii, 149-204.

Parker, Gary J. 1972. Falacias y verdades acerca del quechua, in El reto del multilingüismo en el Perú, ed. A. Escobar. Lima: Instituto de Estudios Peruanos, 11121.

Parker, Gary J. 1973. Derivación verbal en el quechua de Ancash. Working Paper 25. Lima: Universidad Nacional Mayor de San Marcos, Centro de Investigación de Lingüística Aplicada.

Quesada Castillo, Félix. 1973. Fonología y morfología del quechua de Cajamarca. Working Paper 20. Lima: Universidad Nacional Mayor de San Marcos, Centro de Investigación de Lingüística Aplicada.

Quesada Castillo, Félix. 1976a. Diccionario quechua cajamarca-cañaris. Lima: Ministerio de Educación and Instituto de Estudios Peruanos.

Quesada Castillo, Félix. 1976b. Gramática quechua cajamarca-cañaris. Lima: Ministerio de Educación and Instituto de Estudios Peruanos.

Reuse, Willem J. de 1986. The lexicalization of sound-symbolism in Santiago del Estero Quechua. International Journal of American Linguistics 52, 1, 54-64.

Silverman, Helaine and Donald P. Proulx. 2002. The Nasca. Oxford: Blackwell.

Taylor, Gerald. 1979. Morphologie comparée du verbe quechua: l'expression de l'actance, Première partie: Le sujet, in Relations prédicat-actant( $s$ ) dans des langues de types divers II, ed. C. Paris. LACITO-documents Eurasie 3. Paris: SELAF, 171-86.

Taylor, Gerald. 1984. Yauyos: un microcosmo dialectal quechua. Revista Andina 2(1), 121-46.

Taylor, Gerald. 1990. Le dialecte quechua de Laraos, Yauyos: étude morphologique. Bulletin de l'Institut Français d'Études Andines 19(2), 293-325.

Taylor, Gerald. 1994. Estudios de dialectología quechua (Chachapoyas, Ferreñafe, Yauyos). Lima: Universidad Nacional de Educación.

Taylor, Gerald. 1996. El quechua de Ferreñafe. Fonología, morfología, léxico. Cajamarca: Acku Quinde.

Torero, Alfredo A. 1964. Los dialectos quechuas. Anales Científicos de la Universidad Agraria 2(4), 446-78.

Torero, Alfredo A. 1968. Procedencia geográfica de los dialectos quechuas de Ferreñafe y Cajamarca. Anales Científicos de la Universidad Agraria 6(3-4), 291-316.

Torero, Alfredo A. 1972. Lingüística e historia de la sociedad andina, in El reto del multilingüismo en el Perú, ed. A. Escobar. Lima: Instituto de Estudios Peruanos, 46-106. 
Torero, Alfredo A. 1974. El quechua y la historia social andina. Lima: Universidad Ricardo Palma.

Torero, Alfredo A. 1984. El comercio lejano y la difusión del quechua: el caso del Ecuador. Revista Andina 2(2), 367-402.

Torero, Alfredo A. 1994. Las sibilantes del quechua yunga y del castellano en el siglo XVI, in Actas de las II Jornadas Internacionales de Lengua y Cultura Amerindias (Valencia 1993), ed. J. Calvo Pérez. Valencia: Universidad de Valencia, Departamento de Teoría de los Lenguajes, 241-54.

Torero, Alfredo A. 2002. Idiomas de los Andes: lingüística e historia. Lima: Instituto Francés de Estudios Andinos and Editorial Horizonte.

Watanabe, Shinya. 2001. Wari y Cajamarca. Boletín de Arqueología Pontificia Universidad Católica del Perú, 5, 531-41. 
